\title{
DISCREPANCIES IN PERCEPTION AND EVALUATION OF MACROENVIRONMENT - SECTORAL ANALYSIS
}

\author{
Jaroslav BELAS ${ }^{(1)}$, Beata GAVUROVA (D2 ${ }^{*}$, Jan KUBALEK $^{3}$, Matus KUBAK (D) 4 \\ ${ }^{1}$ Faculty of Management and Economics, Tomas Bata University in Zlin, Zlin, Czech Republic \\ ${ }^{2}$ Faculty of Mining, Ecology, Process Control and Geotechnologies of the Technical \\ University of Košice, Košice, Slovak Republic \\ ${ }^{3}$ Faculty of Business Administration, University of Economics Praha, Czech Republic \\ ${ }^{4}$ Faculty of Management, University of Prešov, Prešov, Slovak Republic
}

Received 05 December 2019; accepted 25 February 2020

\begin{abstract}
The aim of presented study is to evaluate macroeconomic environment and to determine differences in perception of macroeconomic environment by entrepreneurs in Slovak Republic and Czech Republic. Data collection was done by questionnaire which was answered by 329 entrepreneurs from Slovak Republic and 312 entrepreneurs from Czech Republic. Topics treated concerning macroenvironment were the favourableness of macroenvironment for business activities, its support for starting an entrepreneurship, its support of innovation activities of companies and its capacity to promote entrepreneurship and to create interesting business opportunities. Answers are divided according to sector in which entrepreneurs doing business. Considered sectors are: transport, trade, construction, production, agriculture, services and other sectors. To analyse collected data, we use correspondence analysis. Results show that there exists systematic difference in perception of macroenvironment by entrepreneurs from SMEs in Slovak Republic and Czech Republic. It seems that entrepreneurs from Czech Republic percept macroenvironment more positively than Slovak ones. Moreover, we document different perception of macroeconomic situation depending on sector in which entrepreneurs operate. Presented research results bring findings for the creators of economic policies. Similarly, presented results form a platform for concepts of strategic and regional plans in order to provide sustainable business environment in the countries, and also their stable economic growth.
\end{abstract}

Keywords: macroeconomics, sectoral analysis, correspondence analysis, macroeconomic indicators, economic policy, regional disparities.

Jel Classification: L26, C80.

\section{Introduction}

Quality of a business environment is created and evaluated at two levels. The first level is a legislative framework and the second level consist of specific social and economic conditions

${ }^{\star}$ Corresponding author. E-mail: beata.gavurova@tuke.sk

This is an Open Access article distributed under the terms of the Creative Commons Attribution License (http://creativecommons. org/licenses/by/4.0/), which permits unrestricted use, distribution, and reproduction in any medium, provided the original author and source are credited. 
in particular regions. Legislative framework defines the amount of tax wedge, it determines the conditions for a business start, it sets a rate of labour market regulations, the accounting rules, as well as a complex of administrative and regulatory duties related to business, etc. These macroeconomic characteristics are not regionally differentiated. Social and economic conditions are regionally differentiated. It is caused by a different development level of transport infrastructure in the regions, industry structure, workforce availability, etc. However, this factor is not considered in a creation of national legislative frameworks, which causes a disproportionate influence of laws on a business environment quality in the individual regions. For instance, labour market regulations and their impacts, etc. (SBA). Favorable business environment including political, technological, economic, social and other determinants is one of the crucial factors influencing the decision to start a business (Kozubikova et al., 2019). Slovakia was ranked as the $39^{\text {th }}$ of 189 countries in 2018 in quality evaluation of a business environment by the World Bank, while the Czech Republic was $30^{\text {th }}$. In 2011, the neighbouring EU Member States, except of Austria, had a business environment at lower quality level. However, the data from 2018 declare a rapid improvement since 2011, apart from Hungary. The countries need to be active in supporting small and mid-size enterprises, and subsequently, they need to support their economic development, use their innovative potential and develop an international co-operation (Cepel et al., 2019). Consequently, business environment will improve in the individual countries and it will eliminate regional disparities and discrepancies that may significantly increase by insufficient policy in the individual locations. Macroeconomic stability is characterized by improving business conditions in the countries.

The aim of the paper is to detect possible differences between Slovak and Czech entrepreneurs perceived in macroeconomic environment in the country, state support in starting an entrepreneurship, state supportive innovation activities of companies and in business opportunities. Paper is organized as follows: firstly, the state of the art is proposed, then data and methodology are presented, third chapter propose analysis and results, followed by discussion. Conclusion can be found in final part of the paper.

\section{Overview of research studies}

Foreign research studies examine various aspects of a business and a business environment as an inevitable part of monitoring economical and social, and economic situation of the countries. Their research has macroeconomic, but also microeconomic character, while the conclusions of these studies have a significant implication potential. A limiting aspect is a significant geographical limitation of a study outputs, as well as their present status with regard to rapid changes in national and international economic environment. Studies' differences are evident in interconnecting analyses' outputs to economic and financial crises. Therefore, macroeconomic business environment represents a challenge for research teams and it also forms a platform for national and international comparative studies.

Zizlavsky (2016) dealt with a process of measuring an innovative efficiency in the Czech business environment in his study. The analysis was realized based on four own surveys. The study results show existing deficiencies in present approaches to measuring of innova- 
tions' efficiency. The Czech businesses have a tendency to neglect research and development area, in spite of the fact, that there is an evident effort to achieve an operational excellence. According to the author, larger enterprises should have a higher intensity of sale connected with innovations, because they may use the advantages of innovations more effectively than SMEs when taking into consideration a necessary level of innovative inputs (due to savings from their size). On the other hand, the SMEs may more effectively use the innovative inputs due to their higher flexibility in production processes. In this context Belás and Sopková (2016) state that larger companies belonging to the segment of SMEs are more innovative, more active and more autonomous in comparison to microenterprises. Kot, Onyusheva and Grondys (2018) also proved that SMEs also adapt supply chain management practices faster then previously studied.

Creation and development of business activities is closely related to the credit risk (Rahman et al., 2019; Androniceanu et al., 2019; Rahman et al., 2017; Sanusi et al., 2017; Belás et al., 2016; Civelek et al., 2016; Belás et al., 2012). It was a subject of a research by the authors Li et al. (2016). The authors tried to apply a new approach to estimate the credit risk for the business credits of the SMEs. The hybrid model connects regression approaches and neural networks.

Consequently, the authors wished to support evaluation processes of financial institutions in providing credits to the SMEs (similary Koisova et al., 2017). In the individual countries, the meaning of a credit scoring had increased as a consequence of banks' financial requirements in post-crisis period (Mihóková, 2017). Also, Fredriksson and Moro (2014) examined relations between the SMEs and a bank sector. The subject of their research and subsequent analyses was a research of the SMEs efficiency, typology of credits and a character of relations between banks and SMEs. The authors state that the SMEs' financial efficiency is related to a bargaining power of businesses. The most significant determinant of obtaining the credit is a strong financial position of companies. SMEs perceive access to finance as the most significant obstacle which hinders their growth. Authors also research other characteristics of businesses, while the main ones are as follows: size, viability, growth rate and ownership. The main obstacles of external financing represent high rental costs and a lack of consultation support. The most important macroeconomic factors that influence SMEs development are as follows: access to financial sources, tax rates, competition, electricity, and political factors. State SMEs have less financial difficulties as opposed to private ones based on the authors' findings. Corazza et al. (2016) were examining worthiness of 40.000 Italian SMEs. They used a modified version of Multi-Criteria Decision Analysis in their analysis. This approach considers various factors that influence the level of business solvency. The results obtained in terms of classification into homogeneous rating classes, scoring and migration probabilities show that the proposed approach is able to unveil early signal of recession in the Italian SMEs sector. Authors show the differences among SMEs, and a necessity to research other determinants of credit relationships and their influence on business. According Ključnikov, Kozubíková and Sopková (2017) the issue of payment discipline is strongly interconnected with the competitiveness of companies. Their results showed that payment discipline represents a major problem in SMEs in Slovakia. 
Psychological factors play an important role in starting a business (Frankovsky et al., 2009), as well. Fairlie and Holleran (2012) examined these factors and their influence on individuals and their preparation for starting their business. The authors used experimental data and they confirm different effects of business preparation of each individual, while a research of psychological specificities of individual were marked as important. Those individuals who prefer independence use entrepreneurship training in a short term horizon more often. Risk tolerance, independence and innovativeness also represent important factors of a business.

Šebestová and Nováková (2015) dealt with innovations in the SMEs development in their study, where they defined determinants and created a suitable model of innovative business behaviour in order to identify investment influence on innovations. Their ambition was to create a platform for a strategy preparation by examining relations between financial indicators and companies' efficiency. The research took place in the Czech and Slovak business environment during 2009 2011, while using the survey questionnaire. The authors evaluate businessmen readiness in a time of global crisis that differentiated them into more groups. Those businessmen who are ready make a profit from a crisis. On the other hand, those businessmen who underestimated global crisis very often suffer from existential crisis. Business men may benefit from doing business in unstable and risky environment by experiencing difficult decision-makings and taking risks. Totally, 670 companies participated in the survey out of which 240 companies were from service sector. Service sector may play an important role in the innovative process as well as in the integrated networks of many areas as services become a part of various levels of the production chain. Striteska and Jelinkova (2015) assess the importance of the SMEs' strategic concepts in their study. Both authors focused on the Czech business environment and realized a comparative analysis in chosen companies. Their conclusions suggest that a higher pressure on companies' competitiveness in a globalized environment leads managers to a constant increase of their performance and strengthening their positions at the market. SMEs accept a fact that their strategic concept has to be dynamic and flexible in order to respond on changes of competitive environment more flexibly. Performance monitoring in different areas of a company is more balanced. However, the field of finance is not dominant anymore, but it is important to monitor customers and processes' sectors.

Rusu and Toderascu (2014) also dealt with researching issues related to a decision-making process of financing the companies. Their study had a macroeconomic character. The authors declare that changes in chosen macroeconomic variables of a country have a significant influence on a decision-making process of financing the analysed companies that also cause various changes in these decision-making processes. The global crisis negatively affected development of the non-financing companies' sector. Financing offer was restricted from the point of a price, but also capacity. Holienka (2015) compared Slovakia with a group of economies which are based on innovations. Business environment influences quantity and quality of business activity in the individual sectors. The policies' creators are supposed to know many aspects of business environment as in the national so in the international context in order to create positive conditions for supporting business efforts. The authors state that there is no adequate environment for innovative business in Slovakia, while they also point to the aspects of regulatory mechanisms, which should form more positive conditions. Popescu 
(2014) examined theoretical interconnection among business, innovations and SMEs. Many economies deeply suffered from a crisis, while they were looking for more strategies of economy revival. In recent years, SMEs' role has especially been emphasized in the innovative activities and processes of technological changes. The authors also show new trends of SMEs, such as a great effort focused on a development of new products, use of new marketing and managerial approaches, and a development of new technologies. Nevertheless, almost 37.55\% of Romanian SMEs do not participate in innovative activities. Authors suggest monitoring of the following indicators: investment ratio searmarked for innovations and turnover ratios created by new products and services. As the main obstacles of innovative processes within SMEs were listed: high costs related to research and development activities, lack of funds and uncertainty, which is related to a high demand of new and innovative products. Serrasqueiro et al. (2018) examined the factors of SMEs' growth and sources of financing before and after a crisis. Authors also identified the following stimulatory factors: cash flows and gross domestic product (GDP), and restriction factors: indebtedness, company size, age and interest rates. The financial crisis and an implementation of restriction measures, which were related to it had a negative influence on a growth of Portuguese SMEs. Macroeconomic environment, that is, the gross domestic product (GDP), inflation rate, trade and labour productivity exibit significant impact on the SME competitiveness in the Central and Eastern European (C.E.E.) countries (Rusu \& Roman, 2018).

A detailed overview of the SMEs development determinants provides study by Chittithaworn et al. (2010). The aim of this study was to examine determinants of the SMEs business success in underdeveloped countries. The SMEs development is stimulated by a private ownership and business skills, as author states. The SMEs flexibility is also very important as it provides prompt reflections on changes of situations at the market, creation of new working opportunities, diversification support of economic activities, etc. Those contribute to a development of business relationships. The study provides an appeal to a deeper research of factors that influence business success that should eliminate risk of losses or companies' bankruptcies, and increase a possibility for success in starting a business within SMEs. Business success is influenced by the following factors: good management and know-how, products and services, different business forms and cooperation, sources, funds, and external business environment. Authors also emphasize a significance of inter-company cooperation that contributes to obtaining of organizational legitimacy and to a development of a good reputation at the market. The inter-company cooperation also enables an improvement of a strategic position of a small company, focus on its main business activity, entering the international markets, optimize the transaction costs, obtain new skills, and positively deal with rapid technological changes. The authors also emphasize an importance of external specialists and consultants.

The institutions also influence business environment besides already mentioned factors. Lisowska (2016) focused on this topic in her study. The aim of this study was to examine use of institutions' potential within a business environment in the SMEs development process. Author contemplates that SMEs interest in institutional support is not sufficient. Therefore, it is necessary to reveal its causes. The analyses' results prove that institutions' network for business environment support in Poland is well-developed. These institutions are especially 
located in large cities and regions with a high economic potential, where a large number of business subjects provide many opportunities for services' diversification. Entrepreneurs who cooperated with institutions from a business environment are aware of all the benefits of this cooperation. The author sees a barrier from SMEs' side that covers a lack of funds for co-financing of business projects and a lack of knowledge of a cooperation options. Similarly, the author sees a barrier from institutions' side that includes insufficient information and promotional activities of institutions, a lack of specialized services, as well as insufficient offer of services for companies. Export directly oriented companies show higher level of progress in innovation, research and development (R\&D) and human capital when compared to indirectly export oriented companies in the Central andEastern European (C.E.E.) and Middle Easternand North African (M.E.N.A.) countries (Cieślik \& Michałek, 2018).

Odehnal and Michálek (2011) researched business environment at micro and macro level in their study. Authors state that active policies, which focus on improvement of business environment quality stimulate a behaviour of local economic subjects, and also influence business environment at two levels, i.e. at the level of micro environment and macro environment. The factors of competitive environment represent possible sources of competitive regions' advantage that compete between each other in order to attract potential investors who would be able to realize their activities in the individual locations. Botlíková and Botlík (2014) tried to map the SMEs development based on the data of the Czech Statistical Office, their databases and strategic documents, and also find a relation between a development of business activities and educational structure. The main initiative of this research was a fact that the Karvina region in the Czech Republic became a restructuring endangered region with a high rate of unemployment. The authors considered a fact which factors would create a competitive region that will be able to offer sufficient conditions for businessmen for doing their businesses. Importance of human capital in a region development was highlighted by the research task.

The research aimed at examining discrepancies in perception and evaluation of macroeconomic environment which depends on sectors of the economy. Simultaneously, the comparative analysis of the results between the Czech Republic and the Slovak Republic was done. The study results represent a valuable source of information for the creators of strategic and regional plans that focus on a development and efficiency of the business environment in both countries.

\section{Data and methodology}

This paper focuses on the perception and evaluation of macroeconomic environment in the companies by entrepreneurs in the Slovak Republic and the Czech Republic. The main aim of the paper is to research the differences in perception and evaluation of macroeconomic business environment on the basis of a sector in which the entrepreneur is running a business. The analysis also focuses on the national view, where a comparison between the Czech Republic and the Slovak Republic is performed.

Data were collected via e-mail inquiry. E-mails were sent to randomly chosen entrepreneurs in the Slovak Republic and the Czech Republic. Data collection took place in 2018. 
The method of random choice using the "Randbetween" mathematical function was used to select enterprises from the "Albertína" database comprising enterprises in the Czech Republic. Slovak enterprises were randomly selected from the "Cribis" database containing the list of enterprises, organizations, and entrepreneurs. The response rate in Slovak Republic was $3.5 \%$ and the response rate in the Czech Republic was approximately $4 \%$.

Questionnaire contained nine constructs: Entrepreneurial support from state, Macroeconomic environment, Quality of entrepreneurship environment, Access to the financial resources, Quality of university education, Personality traits, Entrepreneurships' advantages, Entrepreneurships' disadvantages, Entrepreneurial propensity. Apart from the above-mentioned factors, the entrepreneurs were also asked about their gender, education, size of the company, number of years they run their business, region of business activity, and a sector of a business activity.

Consequently, the focus on the rating of macroeconomic environment of companies by entrepreneurs is examined. Four statements which form Macroeconomic environment construct of questionnaire were chosen. Answers were rated on five level of Likert scale 1 - totally disagree, 2 - disagree, 3 - neutral, 4 - agree, 5 - totally agree. Statements are:

1. Macroeconomic environment in the country is favourable for business activities.

2. State of macroeconomic environment in the country supports starting an entrepreneurship.

3. Current macroeconomic environment supports innovation activities of companies.

4. Current level of macroeconomic indicators promotes entrepreneurship and creates interesting business opportunities.

To process data, we use correspondence analysis. Correspondence analysis is a statistical technique that provides a graphical representation of cross tabulations. Correspondence analysis is an exploratory technique designed for analysing data in pivot tables, while its aim is to reduce a dimensionality. Correspondence analysis provides a measure of correspondence between rows and columns of a pivot table. It allows to study the relationships between two categorical variables, and it is also useful in cases when a graphical output is clearer than numeric outputs. Correspondence analysis is multidimensional visual technique that enables to graphically display the elements of the pivot table and defines the measure of correspondence between its rows and columns. Outputs of the correspondence analysis are similar in its nature to results of a factor analysis. The output of correspondence analysis is a two-dimensional graph, so called correspondence map.

\section{Analysis and results}

Out of 641 collected questionnaires, 329 were from the Slovak Republic and 312 from the Czech Republic. In total, 160 companies operate from 1-5 years, 126 from 5-10 years and 355 are 10 and more years on the market. The dataset consists of 492 micro companies, 114 small companies and 35 medium sized companies. Table 1 provides information about sectorial distribution of the companies, which participated in the analysis. To conclude, the number of companies are more or less equally distributed from the point of view of the country in which they operate. 
Table 1. Sectorial distribution of companies

\begin{tabular}{|l|c|c|c|c|c|c|c|c|}
\hline & \multicolumn{7}{|c|}{ Sector } & \multirow{2}{*}{ Total } \\
\cline { 2 - 8 } & $\begin{array}{c}\text { Trans- } \\
\text { port }\end{array}$ & Trade & $\begin{array}{c}\text { Const- } \\
\text { ruction }\end{array}$ & $\begin{array}{c}\text { Produc- } \\
\text { tion }\end{array}$ & $\begin{array}{c}\text { Agri- } \\
\text { culture }\end{array}$ & Services & Other & \\
\hline $\begin{array}{l}\text { The Slovak } \\
\text { Republic }\end{array}$ & 11 & 69 & 39 & 51 & 20 & 122 & 17 & 329 \\
\hline $\begin{array}{l}\text { The Czech } \\
\text { Republic }\end{array}$ & 16 & 73 & 29 & 53 & 9 & 109 & 23 & 312 \\
\hline Total & 27 & 142 & 68 & 104 & 29 & 231 & 40 & 641 \\
\hline
\end{tabular}

Figure 1 displays the modal answers concerning statement, Macroeconomic environment in the country is favourable for business activities. It is evident that the most frequent modal answer about macroeconomic environment favourableness for business activities is number 2. Thus, the entrepreneurs rather disagree with this statement. Agriculturists in the Slovak Republic completely disagree with this opinion. On the other hand, it seems that agriculturists in the Czech Republic perceive this issue completely differently and declare that they agree with this statement. Differences in opinion may also be found in construction, production and other sectors. It means that the Slovak entrepreneurs are more pessimistic than the Czech ones.

Modal answers concerning statement, State of macroeconomic environment in the country supports starting an entrepreneurship are shown in the Figure 2. Also, in this case, the most frequent modal answer is number 2, meaning disagreement. Similarly, the most pessimistic attitude concerning starting an entrepreneurship has the Slovak agriculturists. On the other hand, the Czech entrepreneurs from construction, agriculture and other sectors are more optimistic than the Slovak ones. In sector of transport, the Slovak entrepreneurs are more optimistic than the Czech ones.

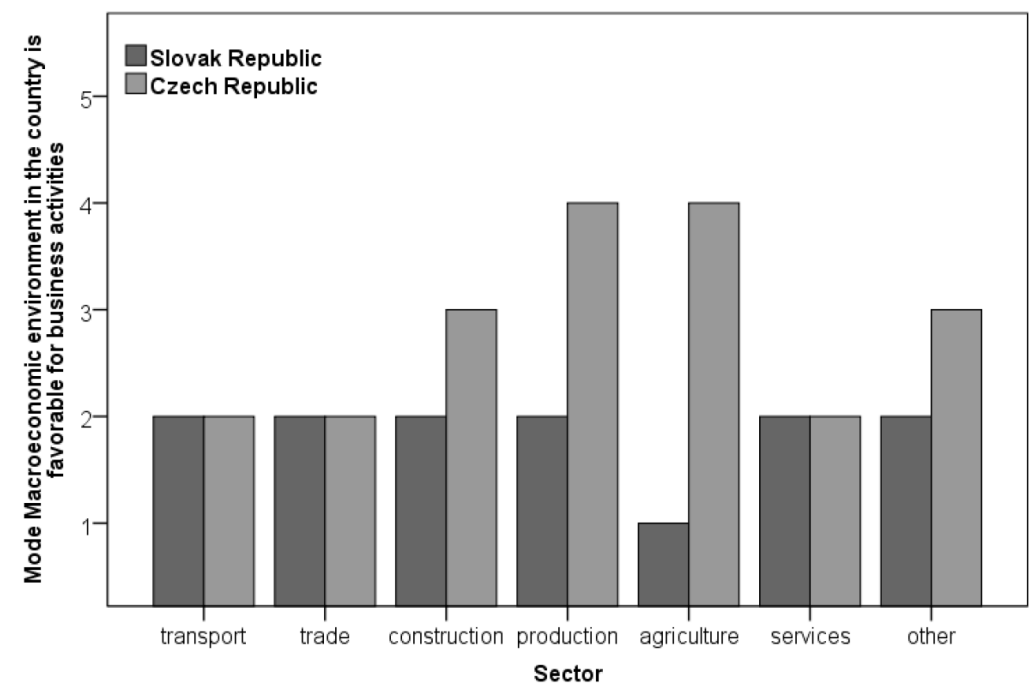

Figure 1. Macroeconomic environment in the country is favourable for business activities 


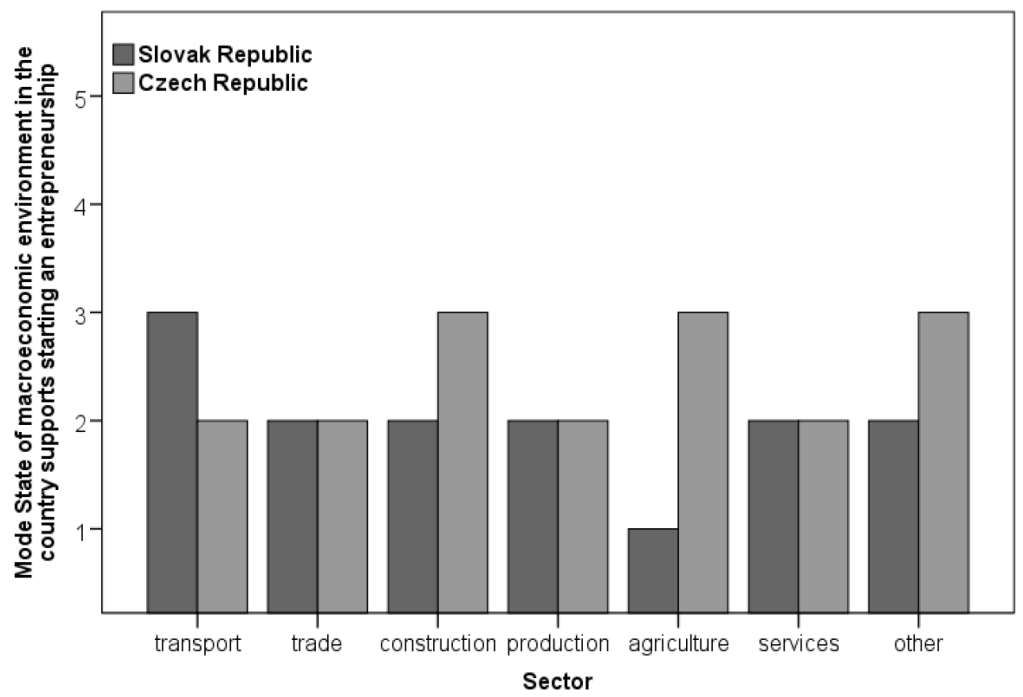

Figure 2. State of macroeconomic environment in the country supports starting an entrepreneurship

In Figure 3, modal answers on the statement, Current macroeconomic environment supports innovation activities of companies, are shown. The structural break in modal answers is obvious, where the value 3 is the most frequent. It means that the entrepreneurs are neutral, or do not take a position on the issue. More pessimistic about this statement are the Slovak entrepreneurs from production sector and other sectors. Similarly as in the previous cases, surprisingly positive response of the Czech agriculturists is evident.

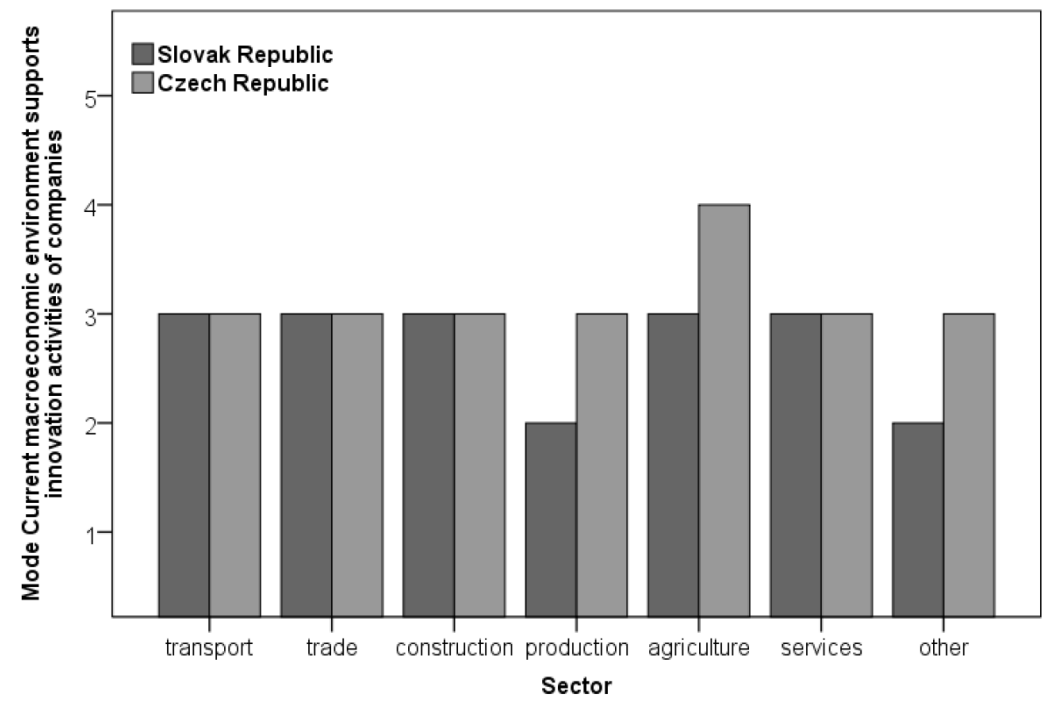

Figure 3. Current macroeconomic environment supports innovation activities of companies 
Finally, Figure 4 captures moral answers concerning statement, Current level of macroeconomic indicators promotes entrepreneurship and creates interesting business opportunities. The biggest disparity of answers in this case when compared to previews statement is evident. The most optimistic about business opportunities are the Czech entrepreneurs from transport and services sectors, and the Slovak entrepreneurs from trade and services sectors. In all other cases, the Slovak entrepreneurs are less optimistic than the Czech ones.

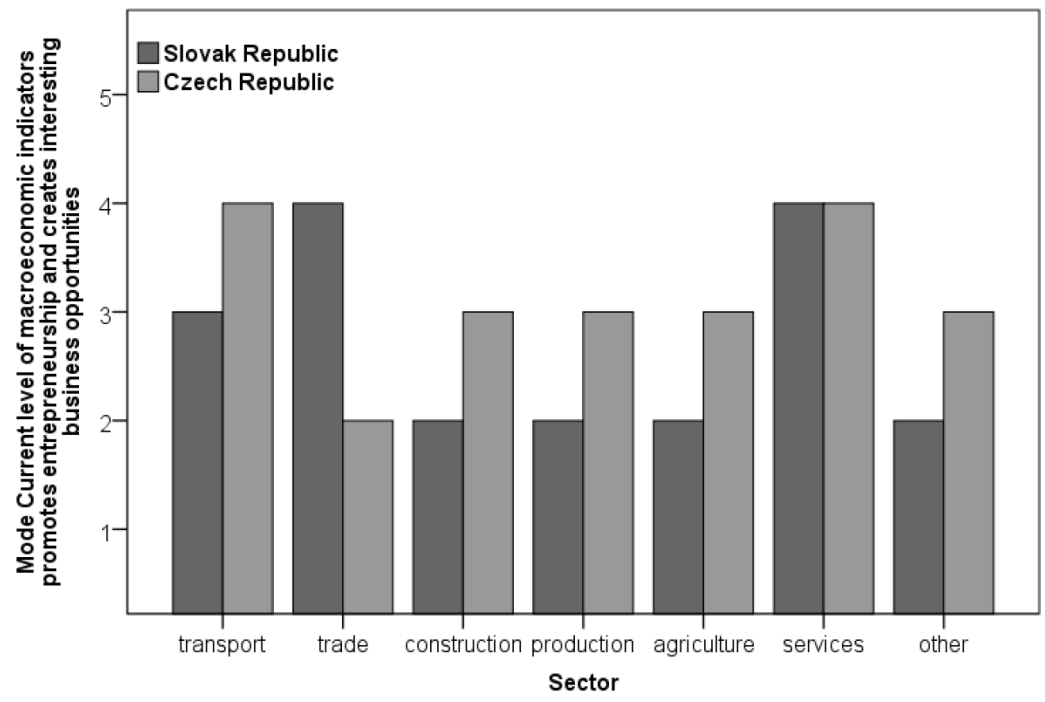

Figure 4. Current level of macroeconomic indicators promotes entrepreneurship and creates interesting business opportunities

In the following lines, the differences revealed by correspondence analysis between responses of entrepreneurs from the Slovak Republic and the Czech Republic in four statements, which form Macroeconomic environment construct of questionnaire, are displayed.

1. Macroeconomic environment in the country is favourable for business activities

Correspondence analysis for the responses of a favourableness of macroeconomic environment for business activities from the Slovak entrepreneurs (Figure 5) captures $80.8 \%$ of total inertia, and from the Czech entrepreneurs 69.9\% (Figure 6) of total inertia. In Figure 5, the Slovak agriculturists correspond with an answer "totally disagree", and the Slovak producers correspond with an answer "disagree". On the other hand, a strong correspondence between answers "agree" and "neutral" are visible in the sectors of transport, construction, services and trade.

In case of the Czech entrepreneurs, a disagreement in the sector of trade and services, neutrality in construction and other sectors and agreement in production are evident.

2. State of macroeconomic environment in the country supports starting an entrepreneurship

Correspondence analysis for responses of supportive macroeconomic environment for starting an entrepreneurship from the Slovak entrepreneurs (Figure 7 ) captures $88.4 \%$ of 


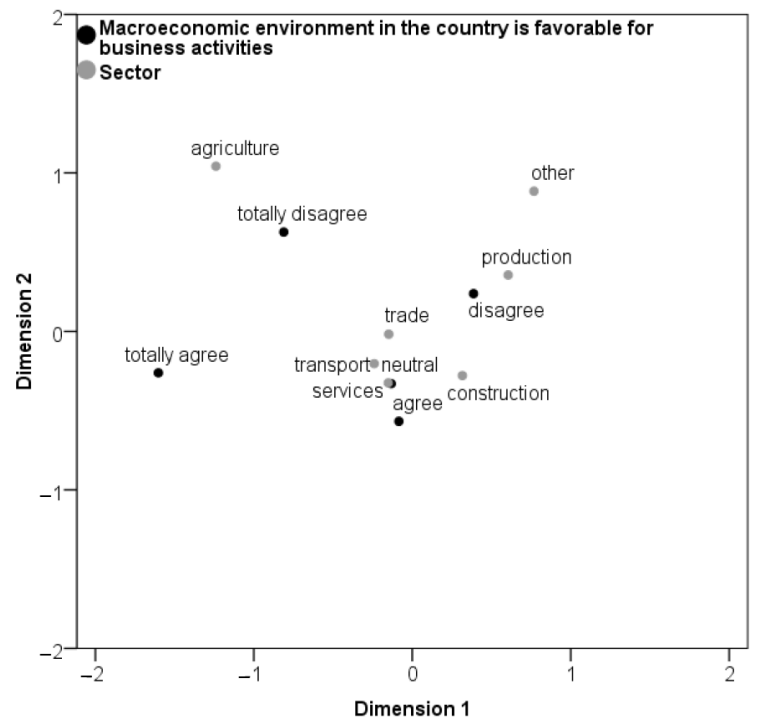

Figure 5. Correspondence analysis/the Slovak Republic

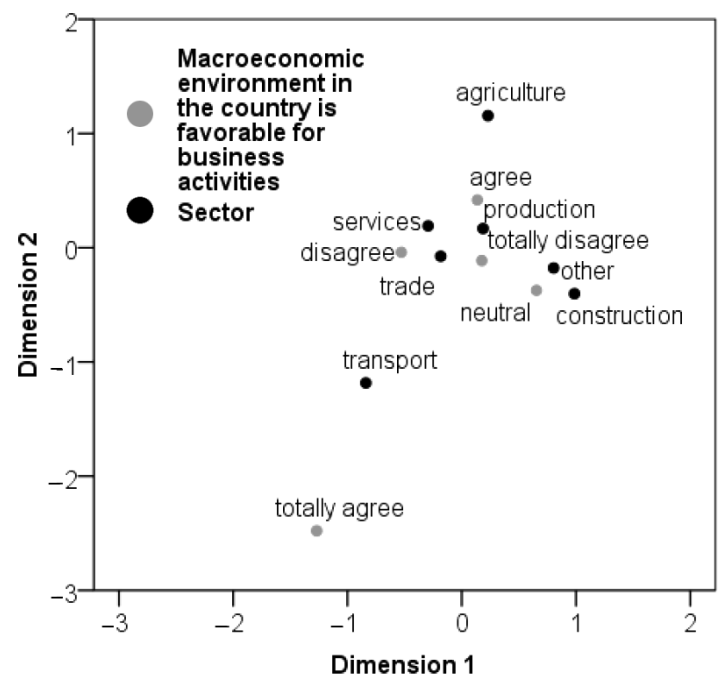

Figure 6. Correspondence analysis/the Czech Republic

total inertia and from the Czech entrepreneurs $80.2 \%$ (Figure 8 ) of total inertia. In case of the Slovak entrepreneurs' answers, there is not any clear correspondence. However, it may be concluded that there is a total disagreement of agriculturists and weak correspondence of transport sector with total agreement.

On contrary, in case of the Czech entrepreneurs, there is evident a weak correspondence of agriculturists and total agreement, neutral opinion of constructions sector and disagreement of sector of services, production and trade. 


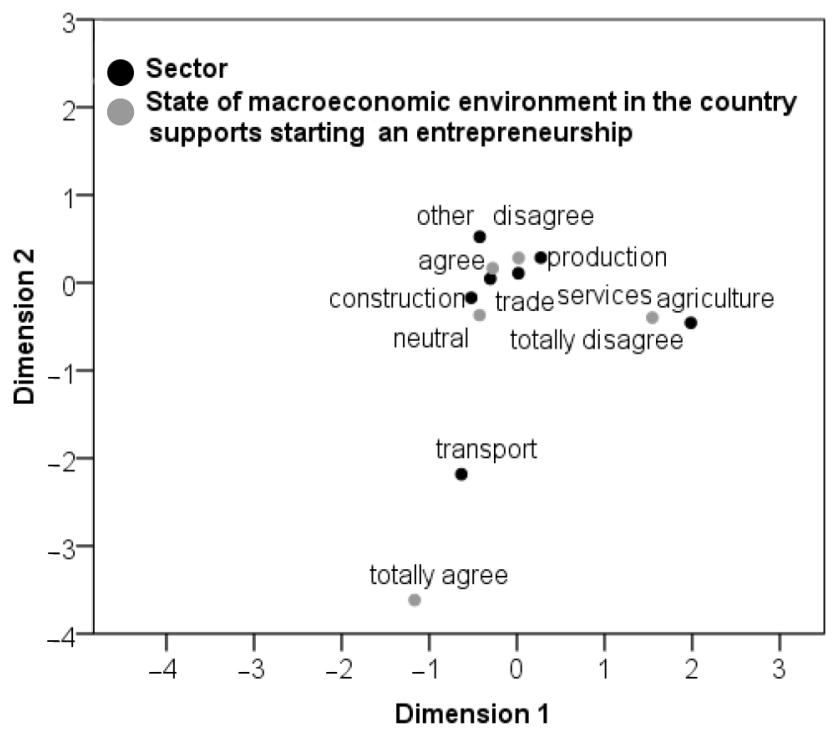

Figure 7. Correspondence analysis/the Slovak Republic

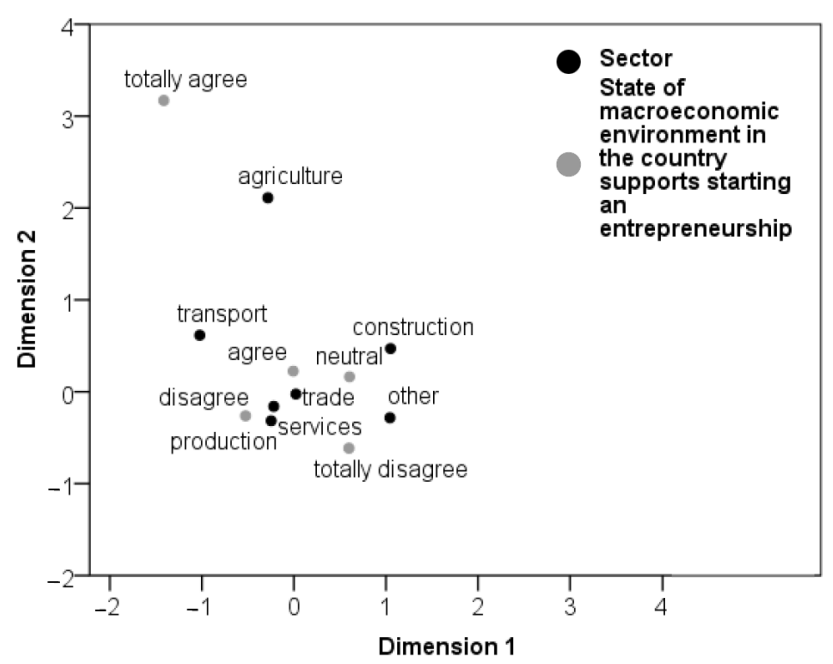

Figure 8. Correspondence analysis/the Czech Republic

3. Current macroeconomic environment supports innovation activities of companies

Correspondence analysis for responses of supportive macroeconomic environment for innovation activities from the Slovak entrepreneurs (Figure 9) captures $84.5 \%$ of total inertia and responses from the Czech entrepreneurs captures 81.6\% (Figure 10) of total inertia.

In case of a supportive macroeconomic environment for innovation activities of companies, the Slovak Republic shows a semi correspondence of agriculture and transport sector with total disagreement. Then, a perfect correspondence between production sector and neutrality and agreement at the same time, and a perfect correspondence between trade and disagreement are evident. 


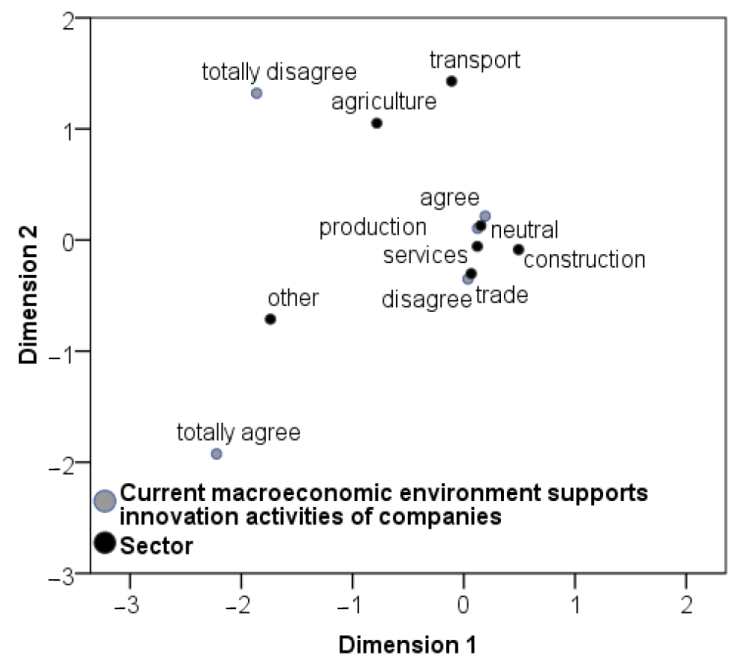

Figure 9. Correspondence analysis/the Slovak Republic

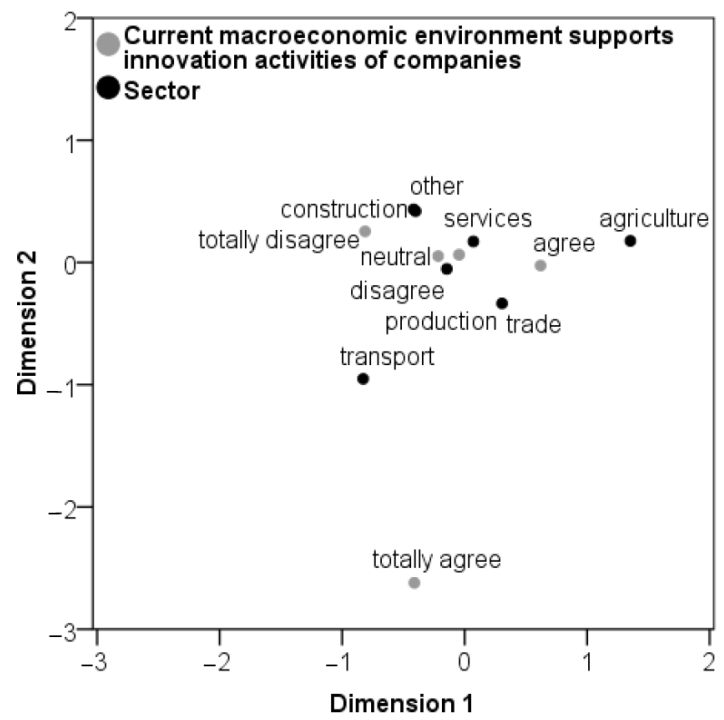

Figure 10. Correspondence analysis/the Czech Republic

In case of supportive macroeconomic environment for innovation activities of companies, the Czech Republic shows a correspondence between agriculture and agreement, and a correspondence between total disagreement and construction sector and other sectors.

4. Current level of macroeconomic indicators promotes entrepreneurship and creates interesting business opportunities

Finally, in case of interesting business opportunities, the correspondence analysis for responses from the Slovak entrepreneurs (Figure 11) captures $74.2 \%$ of total inertia and responses from the Czech entrepreneurs captures $80.4 \%$ (Figure 12) of total inertia. 


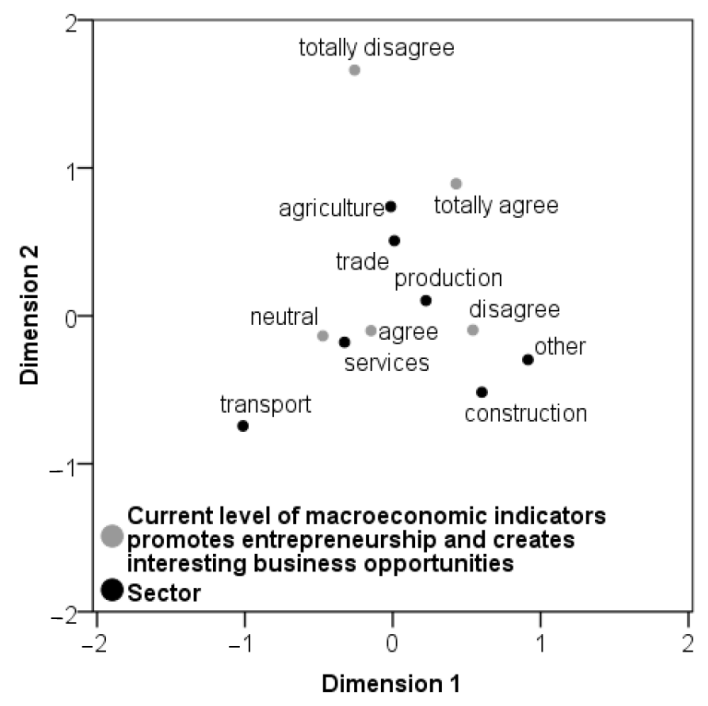

Figure 11. Correspondence analysis/the Slovak Republic

In case of Slovakia, a relationship between transport sector and neutrality, and a correspondence between agreement-neutrality and services may be observed. Furthermore, a correspondence between trade and agriculture and total disagreement are evident. A correspondence between disagreement and other sectors and construction sector may be observed, as well.

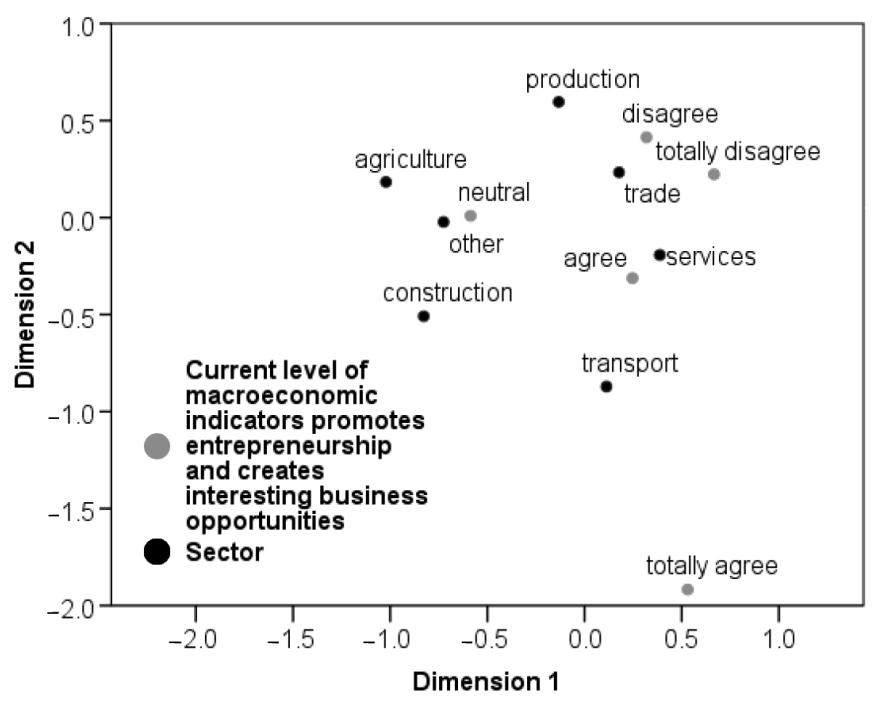

Figure 12. Correspondence analysis/the Czech Republic

The Czech entrepreneurs show a cluster of neutrality and agriculture, construction and other sectors, cluster of disagreement, and/or total disagreement, and trade and production, and cluster of agreement and transport and services. 


\section{Discussion}

Companies face serious challenges that are connected with a competitiveness due to the present economic situation. The economies of the countries are more focused on the processes related to innovations and applied research as well as on other long-term factors of economic and social development for the past years. The companies need to increase their competitiveness by implementing progressive technologies, decreasing energy intensity of the economy, improving the sector efficiency and attractiveness, such as tourism, educational systems, etc. Innovative development is determined by a company's size as well as its economic sector. As many studies prove (Gavurova et al., 2017a; Behun et al. 2018; Civelek et al., 2016; Belás et al., 2016), medium and large companies were focused on operational effectiveness and cost savings for a longer period of time, while a certain space for smaller companies had been created in order to respond to the environmental changes by innovations. Many research studies also prove that the more organizationally-challenged company, the lower is its adaptability to innovative changes (Hudec \& Šebová, 2012; Gavurova et al., 2017c; Belás \& Sopkova, 2016; Rahman et al., 2017). Consequently, many smaller companies, which have more flexible organizational structure, were innovated for the past years. Also, large companies support innovations, but the positive impacts of these activities are reflected later (Gavurova et al., 2017b).

The analytical part of this study focuses on evaluation of macroeconomic environment's perception by the businessmen in the Czech Republic and the Slovak Republic, while taking into consideration the sector differentiation. The subject of the research is based on the statements, which rated the following: macroeconomic environment in a country and its positive influence on business activities; status of the macroeconomic environment in a country and its support of start-ups and innovative activities of companies. Therefore, the research also focused on a present level of macroeconomic indicators and their support of business, and creation of interesting business opportunities as the macroeconomic stability represents a signal of improved business conditions in a country.

The analysis's results revealed many interesting findings. In examining respondents' responses on the statement that the macroeconomic environment in their country has a positive influence on business activities showed disagreement on entrepreneurs' sides. The Slovak farmers totally disagree with this statement. However, a different perception was notices in farmers from the Czech Republic who claim that the macroeconomic environment in their country is favourable for business activities. The different opinions were also found in the following sectors: civil engineering, production, as well as in other sectors. It may be stated that the Slovak entrepreneurs are more pessimistic than the Czech ones. The statement that the macroeconomic environment in a country supports the start-ups again showed disagreement. The most pessimistic approach to business prevails in the Slovak farmers. The Czech entrepreneurs in civil engineering, farming, as well as in other sectors are more optimistic than the Slovak ones. On contrary, the Slovak entrepreneurs in the transport sector express their positive attitude to the macroeconomic environment that supports start-ups as opposed to the Czech entrepreneurs in the same sector. In the third group of researched findings, where the study focused on the statement that the present macroeconomic environment 
supports innovative activities of a company, showed a structural discontinuity in the modal responses. The most frequent value was 3 , which means that the entrepreneurs were neutral or not interested in the statement of this question. The pessimistic approach to this question was evident in the Slovak entrepreneurs from a production sector, as well as from other sectors. Also, in this case, the Czech farmers positively responded to this question. The last question examined whether the present level of the macroeconomic indicators supports business and creates interesting business opportunities. The most evident difference in opinions was present in this question. The most optimistic attitude expresses the Czech entrepreneurs from the transport and services sector, and the Slovak entrepreneurs from the sector of commercial and public services. The Slovak entrepreneurs are less optimistic in the rest of the sectors than the Czech entrepreneurs.

The findings that the different results in perception of examined macroeconomic environment factors in relation to a support of start-ups, innovative activities and provision of favourable conditions for business activities also correspond with the findings from the following studies: Koisova et al. (2017), Lisowska (2016), Holienka (2015), Botlíková and Botlík (2014).

Both countries face many important challenges from these findings. It is inevitable to examine economic activities in the individual regions of both countries and to focus on the regional disparities and discrepancies, while highlighting the differentiation aspects in the individual sectors of economy. It is a continuation of this research. Consequently, it is also necessary to support economic activity in less developed regions, where a potential of sufficient labour and relatively lower labour costs are present. However, even these measures will not be sufficient in maintaining growth potential of both economies from a long-term perspective. In the future, both countries will suffer from a lack of labour and increase of wages that would lead to pressures on productivity increase, competitiveness and innovative potential increase. SMEs will still significantly participate in the economic activities of the countries. SMEs' significance will be the most evident in those regions which will be of no interest for the foreign investors. Similarly, in these regions, SMEs will represent the main source of working opportunities, the main local capital and a driver for the economic development of the regions. They will also represent a potential of national economies' growth as well as a tool for eliminating the regional disparities. It is difficult to find an appropriate rate of business environment interventions in spite of an existence of agencies and institutions that support SMEs' development and their support in policies' creation for improving the macroeconomic business environment. It is important to provide such rules, which are set by the governments of both countries, that would not be bureaucratic and complicated, and the entrepreneurs would be able to perceive and accept them. The role of a state and the limits of business environment in both countries declare an obvious potential for improvement at national and international level. On the other hand, insufficient potential in developing the business activities decreases an attractiveness of a business environment for the foreign investors, as well. The business environment is directly interconnected with the labour market. Labour market in both countries is not flexible from a perspective of required qualification (educational institutions do not flexibly respond to a structure of labour demand) even this situation has been improving in these processes. Strong competitiveness among companies 
will result in higher criteria on a qualified labour. Also, this factor will influence the business activities in various sectors of economy and their development.

In conclusion, small entrepreneurs will have difficulties in all sectors to obtain the bank resources of a financing as for start-ups so for business development in spite of a different perception of the researched characteristics of the macroeconomic environment in various sectors of both countries. The entrepreneurs will constantly face costs increase, especially increasing prices of energies, etc. The role of institutions and their tools that focus on providing direct and indirect support of small and medium-sized entrepreneurs is a subject of discussion these days. On the other hand, an increase of administrative burden in order to obtain various types of support, etc. is also evident. The payment morality and an approach to relevant information of a debtor's credit history, etc. have a significant influence on a business development. All aspects, even those which are not mentioned, influence business development in a country and create a potential for an internal integrity of citizens' efforts. Thus, it is inevitable to remove all factors, including microeconomic and macroeconomic that prevent active and successful development of macroeconomic business environment.

\section{Conclusions}

The present macroeconomic situation of the EU countries force specialists to examine and evaluate the main obstacles that companies deal with in decision-making processes of startups, as well as financial and technical questions. The decision-making processes of companies' financing are significantly influenced by a development of macroeconomic indicators in a country. Each change in the macroeconomic business environment interferes with business process management that influence its further efficiency and stability. Many changes in the macroeconomic business environment were initiated by the impacts of financial and economic crises. Their positive aspect lies in a fact that both brought many initiatives and challenges to a business, and simultaneously, both implicitly contribute to a creation of active policies. These facts represent a basis for a realization of this research, whose aim is to research discrepancies in a perception and evaluation of the macroeconomic business environment with a focus on the sector analysis. Correspondence analysis was chosen to evaluate the responses of the respondents from the Czech Republic and the Slovak Republic. Questionnaire form was chosen to collect data. The respondents were entrepreneurs whose companies were from different sectors of economy of both countries. Interesting findings were found from respondents' responses. In researching the statement that the macroeconomic environment has a positive influence on business activities provide significant differences among the sectors. A strong equivalence may be seen among "Agree" and "Neutral" responses, and the sector of transport, civil engineering, commercial and public services. In case of the Czech entrepreneurs, an equivalence was found in "Disagree" responses in the commercial and public services sector, "Neutral" responses in civil engineering sector and other sectors, and "Agree" responses in a production. In researching the statement that the macroeconomic environment in a country supports a business does not provide any exact equivalence in terms of the Slovak entrepreneurs. However, an equivalence may be found in "Totally Disagree" responses of the farmers, and a weaker equivalence in "Totally Agree" 
responses in the transport sector. The statement that the present macroeconomic environment supports innovative activities of the companies also brought different findings. In the Slovak Republic, there was found out a half correspondence of "Totally Disagree" responses in the economic and transport sector, and a perfect correspondence of "Neutral" and "Agree" responses at once in the production sector. Similarly, a perfect correspondence of "Disagree" responses was found out in the commercial sector. In the Czech Republic, an equivalence of "Agree" responses were found out in the economic sector, and of "Totally Disagree" responses in the civil engineering sector and other sectors. The last part of the research focused on the present level of the macroeconomic indicators and their support of a business and creation of interesting business opportunities. In case of the Slovak Republic, an equivalence of "Neutral" responses were found out in the transport sector, and of "Agree" and "Neutral" responses in the public services' sector. Also, an equivalence of "Totally Disagree" responses was found out in the commercial and economic sectors. Other findings show and equivalence of "Disagree" responses in other sectors and the civil engineering sector. In case of the Czech Republic, "Neutral" responses in the economic, civil engineering sectors and other sectors were found out. Also, "Disagree" responses in the commercial and production sectors were found out, while "Agree" responses were found out in the transport and public services' sectors. The given findings show a strong sector differentiation in a perception of the macroeconomic business environment influence on the business activity, business start-up, innovations and other business opportunities. This motivates researchers to perform more researches in order to reveal the regional disparities within this sector analysis and to search for other options of setting the regulation and stabilization mechanisms to support business in other sectors, as well as regions. The role of the sectoral policies is important as they are related to a good quality analytical platform. Many national agencies and institutions monitor and report a status and development of the macroeconomic environment. However, it is important to bring different perspectives into these reports and consequently, to reveal deeper connections of issues in a development of the business activities. It is also important to research positions of a private sector in the individual sectors, which would bring many interesting findings. However, there is an absence of data of a private sector's position in the individual sectors in the national registers. Also, there does not exist any overall overview of the business subjects under state surveillance. Data availability would bring other interesting research aspect and would reveal possibilities of improvement the macroeconomic environment that would enable stable economic growth and a gradual elimination of the regional disparities in the economic and social areas.

\section{Acknowledgements}

This work was supported by the Scientific Grant Agency of the Ministry of Education, Science, Research and Sport of the Slovak Republic and the Slovak Academy Sciences as a part of the research project VEGA 1/0797/20: "Quantification of Environmental Burden Impacts of the Slovak Regions on Health, Social and Economic System of the Slovak Republic". 


\section{References}

Androniceanu, A., Gherghina, R., \& Ciobanasu, M. (2019). The interdependence between fiscal public policies and tax evasion. Administratie si Management Public, 32, 32-41.

https://doi.org/10.24818/amp/2019.32-03

Behun, M., Gavurova, B., Tkacova, A., \& Kotaskova, A. (2018). The impact of the manufacturing industry on the economic cycle of European Union countries. Journal of Competitiveness, 10(1), 23-39. https://doi.org/10.7441/joc.2018.01.02

Belás, J., \& Sopková, G. (2016). A model of entrepreneurial orientation. Transformation in Business \& Economics, 15(2B), 630-645.

Belás, J., Cipovová, E., Novák, P., \& Polách, J. (2012). Impacts of the foundation internal ratings based approach usage on financial performance of Commercial Bank. E+M Ekonomie a Management, 15(3), 142-154.

Belás, J., Vojtovič, S., \& Ključnikov, A. (2016). Microenterprises and significant risk factors in loan process. Economics and Sociology, 9(1), 43-59. https://doi.org/10.14254/2071-789X.2016/9-1/3

Botlíková, M., \& Botlík, J. (2014). Analysis of the business environmenting. In $17^{\text {th }}$ International Colloquium on Regional Sciences, 239-246. https://doi.org/10.5817/CZ.MUNI.P210-6840-2014-29

Cepel, M., Kljucnikov, A., Kozubikova, L., \& Krajcik, V. (2019). Local currency as a mean of regional competitiveness development. Journal of Competitiveness, 11(4), 22-39. https://doi.org/10.7441/joc.2019.04.02

Chittithaworn, CH., Islam, A., Keawchana, T., \& Yusuf, D. H. M. (2010). Factors affecting business success of Small \& Medium Enterprises (SMEs) in Thailand. Asian Social Science, 7(5), 180-190. https://doi.org/10.5539/ass.v7n5p180

Cieślik, A., \& Michałek, J. J. (2018). Firm-level determinants of direct and indirect exports: Empirical evidence for C.E.E. and M.E.N.A. countries. Economic Research-Ekonomska Istraživanja, 31(1), 982-996. https://doi.org/10.1080/1331677X.2018.1436452

Civelek, M., Ključnikov, A., Dobrovič, J., \& Hudáková, M. (2016). A model of measurement of the quality of business environment in SME segment. Journal of International Studies, 9(2), 90-102. https://doi.org/10.14254/2071-8330.2016/9-2/6

Corazza, M., Funari, S., \& Gusso, R. (2016). Creditworthiness evaluation of Italian SMEs at the beginning of the 2007-2008 crisis: An MCDA approach. The North American Journal of Economics and Finance, 38, 1-26. https://doi.org/10.1016/j.najef.2016.05.008

Fairlie, R. W., \& Holleran, W. (2012). Entrepreneurship training, risk aversion and other personality traits: Evidence from a random experiment. Journal of Economic Psychology, 33(2), 366-378. https://doi.org/10.1016/j.joep.2011.02.001

Frankovsky, M., Istvanikova, L., \& Stefko, R. (2009). Strategies of behavior in demanding managerial work situations in social contexts. Studia Psychologica, 51(2-3), 231-236.

Fredriksson, A., \& Moro, A. (2014). Bank-SMEs relationships and banks' risk-adjusted profitability. Journal of Banking \& Finance, 41, 67-77. https://doi.org/10.1016/j.jbankfin.2013.12.026

Gavurova, B., Behunova, A., Tkacova, A., \& Perzelova, I. (2017a). The mining industry and its position in the economic cycle of the EU countries. Acta Montanistica Slovaca, 22(3), 278-286.

Gavurova, B., Packova, M., Mišankova, M., \& Smrčka, L. (2017b). Predictive potential and risks of selected bankruptcy prediction models in the Slovak business environment. Journal of Business Economics and Management, 18(6), 1156-1173. https://doi.org/10.3846/16111699.2017.1400461

Gavurova, B., Virglerova, Z., \& Janke, F. (2017c). Trust and a sustainability of the macroeconomic growth insights from dynamic perspective. Journal of Security and Sustainability Issues, 6(4), 637-648. https://doi.org/10.9770/jssi.2017.6.4(9) 
Holienka, M. (2015). Entrepreneurial environment in Slovakia: Multi-perspective comparison with innovation-driven economies. Procedia Economics and Finance, 34, 437-444.

https://doi.org/10.1016/s2212-5671(15)01652-4

Hudec, O., \& Šebová, M. (2012). The ICT sector evolution in an industrial region of Slovakia. Ekonomický časopis, 60(1), 65-82.

Ključnikov, A., Kozubíková, L., \& Sopková, G. (2017). The payment discipline of small and mediumsized enterprises. Journal of Competitiveness, 9(2), 45-61. https://doi.org/10.7441/joc.2017.02.04

Koisova, E., Habanik, J., Virglerova, Z., \& Rozsa, Z. (2017). SMEs financing as an important factor of business environment in Slovak Republic regions. Montenegrin Journal of Economics, 13(2), 129-140. https://doi.org/10.14254/1800-5845/2017.13-2.8

Kot, S., Onyusheva, I., \& Grondys, K. (2018). Supply chain management in SMEs: Evidence from Poland and Kazakhstan. Engineering Management in Production and Services, 10(3), 23-36. https://doi.org/10.3390/su10041143

Kozubikova, L., Kotaskova, A., Dvorsky, J., \& Kljucnikov, A. (2019). The impact of political factors perception on suitability of international business environment: The case of startups. Economics and Sociology, 12(1), 61-79. https://doi.org/10.14254/2071-789X.2019/12-1/3

Li, K., Niskanen, J., Kolehmainen, M., \& Niskanen, M. (2016). Financial innovation: Credit default hybrid model for SME lending. Expert Systems with Applications, 61, 343-355. https://doi.org/10.1016/j.eswa.2016.05.029

Lisowska, R. (2016). The potential of business environment institutions and the support for the development of small and medium-sized enterprises. Entrepreneurial Business and Economics Review, 4(3), 85-101. https://doi.org/10.15678/eber.2016.040307

Mihóková, L. (2017). Fiscal consolidation start and its determinants analysis within European member countries. Montenegrin Journal of Economics, 13(3), 135-147.

https://doi.org/10.14254/1800-5845/2017.13-3.11

Odehnal, J., \& Michálek, J. (2011). Empirická analýza regionálního podnikatelského prostředí vybraných zemí EÚ. Politická ekonomie, 1, 242-262. https://doi.org/10.18267/j.polek.783

Popescu, N. E. (2014). Entrepreneurship and SMEs innovation in Romania. Procedia Economics and Finance, 16, 512-520. https://doi.org/10.1016/s2212-5671(14)00832-6

Rahman, A., Belas, J., Kliestik, T., \& Tyll, L. (2017). Collateral requirements for SME loans: Empirical evidence from the Visegrad countries. Journal of Business Economics and Management, 18(4), 650-675. https://doi.org/10.3846/16111699.2017.1357050

Rahman, A., Tvaronaviciene, M., Smrcka, L., \& Androniceanu, A. (2019). The effect of Bank Competition on the cost of credit: Empirical evidence from the Visegrad Countries. Acta Polytechnica Hungarica, 16(4), 175-195. https://doi.org/10.12700/APH.16.4.2019.4.9

Rusu, D. V., \& Roman, A. (2018). An empirical analysis of factors affecting competitiveness of C.E.E. countries. Economic Research-Ekonomska Istraživanja, 31(1), 2044-2059. https://doi.org/10.1080/1331677X.2018.1480969

Rusu, V. D., \& Toderascu, S. C. (2014). Enterprise financing in the context of macroeconomic instability. Evidence from CEE countries. Procedia Economics and Finance, 15, 730-737. https://doi.org/10.1016/s2212-5671(14)00440-7

Sanusi, K. A., Meyer, D., \& Ślusarczyk, B. (2017). The relationship between changes in inflation and financial development. Polish Journal of Management Studies, 16(2), 253-265. https://doi. org/10.17512/pjms.2017.16.2.22

Serrasqueiro, Z., Leitão, J., \& Smallbone, D. (2018). Small- and medium-sized enterprises (SME) growth and financing sources: Before and after the financial crisis. Journal of Management \& Organization, pp. 1-16. https://doi.org/10.1017/jmo.2018.14 
Striteska, M., \& Jelinkova, L. (2015). Strategic performance management with focus on the customer. Procedia - Social and Behavioral Sciences, 210, 66-76. https://doi.org/10.1016/j.sbspro.2015.11.330

Šebestová, J., \& Nowáková, K. (2015). Innovation spirit evaluation within service organizations: The case of the Czech Republic. Procedia - Social and Behavioral Sciences, 181, 241-250. https://doi.org/10.1016/j.sbspro.2015.04.885

Zizlavsky, O. (2016). Innovation performance measurement: Research into Czech business practice. Economic Research-Ekonomska Istraživanja, 29(1), 816-838.

https://doi.org/10.1080/1331677x.2016.1235983 